\title{
How To Manage Extravasation Of Ibandronic Acid?: A Case Report
}

\author{
Ekstravaze olan ibandronik asit nasıl tedavi edilir?: Vaka takdimi \\ Ender Salbaş ${ }^{1}$, Ali Yavuz Karahan², Levent Tekin³ ${ }^{3}$ Banu Ordahan ${ }^{4}$, Sertaç Ketenci ${ }^{5}$ \\ 1 Physical Medicine and Rehabilitation Education Research Hospital, Ömer Halisdemir University, Bor, Niğde/Turkey \\ 2 Physical Medicine and Rehabilitation Department, Uşak University, Uşak/Turkey \\ 3 Physical Medicine and Rehabilitation Department, Beyhekim Government Hospital, Konya / Turkey \\ 4 Physical Medicine and Rehabilitation Department, Konya Education Research Hospital, Konya/Turkey \\ 5 Rheumatology Department, Giresun University Medical Faculty, Giresun/Turkey
}

\section{özeT}

Ibandronik Asit (IA), osteoporozun önlenmesi ve tedavisinde kullanılan güçlü bir bifosfonattır. Ayrıca hiperkalsemi (yüksek kan kalsiyum seviyeleri) tedavisinde de kullanılabilmektedir. Artralji, femur kırı̆̆ı, ekstremitede ağrı, ishal, kas ağrısı, mide bulantısı, sırt ağrısı, ağrı ve kemik ağrısı FDA'ya bildirilen en sık yan etkilerdir. Bu olgu sunumu ile i̇ ekstravazasyonunu ele alacağız. Bifosfonat kullanan bir osteoporotik kadın hastaya intravenöz IA uygulanırken, IV solüsyonun neredeyse tamamı yanlışıkla ekstravaze olmuş. Iki saat sonra iğne giriş bölgesinde, sağ dirsek fleksör tarafta yanma ve orta derecede kaşıntı hissi ve hafif milimetrik eritem gelişen hasta bu durum hakkında kimseye bilgi vermemiş. Sonraki gün eritematöz alan 5-6 cm'ye çıkıp semptomların kötüleşmesi üzerine polikliniğine başvurdu. Ayrıca kusma ve ishal şikâyeti vardı. "Bu hastanın osteoporoz tedavisinin bu durumdan sonra nasıl devam etmesi gerektiği” sorusunu da tartışmak istiyoruz..

Anahtar Kelimeler: Ekstravazasyon, ibandronik asit, yönetim, korunma

\section{ABSTRACT}

Ibandronic acid (IA) is a potent bisphosphonate drug used in the prevention and treatment of osteoporosis. It may also be used to treat hypercalcemia (elevated blood calcium levels). Arthralgia, femur fracture, pain in extremity, diarrhea, myalgia, nausea, back pain, pain, and bone pain are most common adverse events of the IA reported to the FDA. We discourse a case of IA extravasation in this presentation. An osteoporotic woman who was using bifosfonate medications had applied intravenous IA, but almost all of the solution was extravasated accidentally. Two hours later she noticed burning and moderate itching sensation and slight millimeter erythema at the flexure of the right elbow in the region of venipuncture but she had decided not to inform. Although the day after the erythematous area had increased to 5-6 cm and the symptoms worsened, she revisited the outcome clinic. Also, she had a complaint of vomiting and diarrhea. Also, we want to discuss the question of "How this patient's osteoporosis treatment should be continued after this situation?"

Keywords: Extravasation, ibandronic acid, management, prevention

\section{OBJECTIVE}

Ibandronic acid (IA) is a potent bisphosphonate drug used in the prevention and treatment of osteoporosis (1). It may also be used for hypercalcemia treatment (elevated blood calcium levels) (2). Arthralgia, femur fracture, pain in extremity, diarrhea, myalgia, nausea, back pain, pain, and bone pain are most common adverse events of the IA reported to the FDA (Figure-1). Extravasation is the much more rare complication of IA. Extravasation is the accidental administration of intravenously (i.v.) infused medications like IA into the extravascular space/tissue around infusion sites, either by leakage (e.g., because of brittle veins in very elderly patients), previous venipuncture (such as from blood drawn for laboratory tests prior to therapy), or direct leakage from mispositioned venous access devices (3).

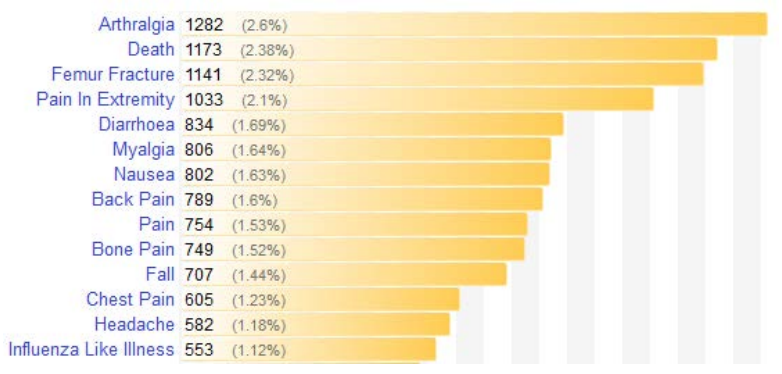

Figure 1. Most common adverse events of ibandronic acid reported to the Food and Drug Administration

Extravasation of medication during IV therapy is an adverse event related to treatment that, depending on the

Yazışma Adresi/Address for Correspondence: Physical Medicine and Rehabilitation Education Research Hospital, Ömer Halisdemir University, Bor, Niğde/Turkey

E-Posta/E-Mail: drender@yandex.com || Tel: +905556698639

Received/Geliş Tarihi: $12 \mathrm{Haz} 2018$ || Accepted/Kabul Tarihi: 13 Ağu 2018

Bu Eser Creative Commons Atıf-Gayriticari 4.0 Uluslararası Lisansı Ile Lisanslanmıştır. This work is licensed under a Creative Commons

Attribution-NonCommercial 4.0 International License (CC BY-NC 4.0). 
medication, amount of exposure, and location, can potentially cause severe injury and permanent harm, such as tissue necrosis. Although IA causes milder consequences of extravasation to include irritation, characterized by symptoms of pain and inflammation, with the clinical signs of warmth, erythema, or tenderness.

We discourse a case of IA extravasation in this presentation..

\section{CASE}

A 65-year-old postmenopausal Turkish woman came to outpatient clinic for her annual checkup. She has been in good general health for the past several years. She has undergone menopause in her early 50 s and used hormone therapy (HT) with estrogen/progestin for her menopausal symptoms for two years; she has remained on hormone and vitamin $D$, therapy primarily for prevention of osteoporosis. She has no personal history of fractures, her older sister experienced a hip fracture and currently not on any chronic medications other than HT. She is $154 \mathrm{~cm}$ 's and weighs $68 \mathrm{kgs}$. She drinks several cups of coffee per a day, and rarely exercises and does not smoke cigarettes. Her height has remained stable. A physical exam was performed, with no abnormalities noted. Measurement of the patient showed no loss of height over the last several years. Assessment of her caloric, vitamin D, and calcium intake is consistent. A bone mineral density (BMD) test performed on this patient revealed lumbar spine (L1-L4) vertebra T-score of -3.1 and left hip T-score of -2.5 . Laboratory results revealed standard serum chemistries and complete blood count. Urinary calcium excretion was slightly elevated. Serum 25-hydroxyvitamin D and thyrotropin and urinary-free cortisol values were all within the normal reference range. Based on these results, no secondary causes for low bone mineral density were identified. So ibandronic acid three $\mathrm{mg} / 3 \mathrm{dl}$ prescribed with calcium and vitamin d supplements. She had applied intravenous IA, but almost all of the solution was extravasated accidentally. Two hours later she noticed moderate itching sensation, burning, and slight millimeter erythema at the flexure of the right elbow in the region of venipuncture but she decided not to inform.

Although the day after the erythematous area had increased to $5-6 \mathrm{~cm}$ and the symptoms worsened, so she revisited the outcome clinic (Figure 2). Also, she had a complaint of vomiting and diarrhea. At that moment she was recommended to apply topical hydrocortisone ointment twice a day and cooling with ice packets. Her lesion was healed in two weeks. We have considered continuing her treatment with oral ibandronic acid instead of IV application. But we could not find a right answer for "How soon after the new medication must be started after this event?".

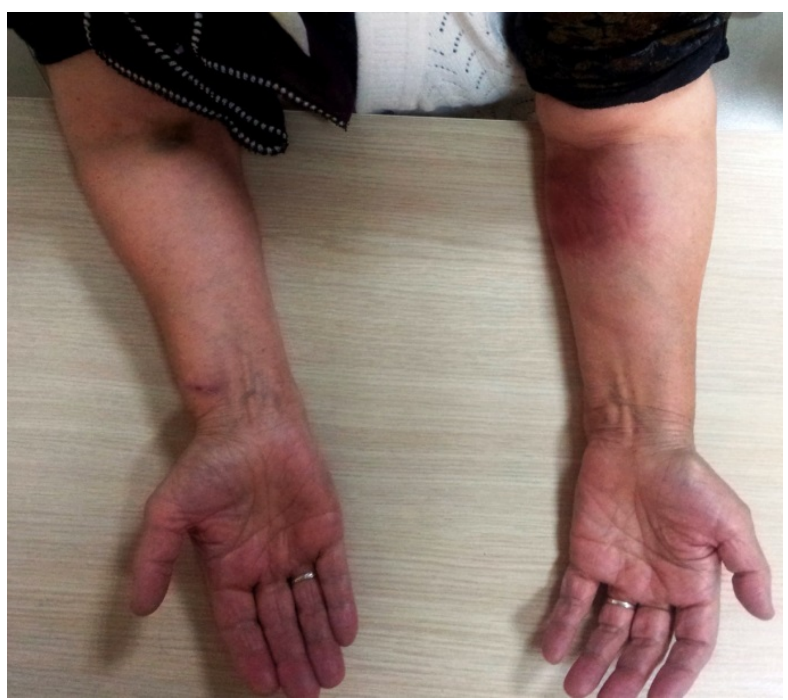

Figure 2. The appearance of the skin one day after extravasation

\section{DISCUSSION}

Bisphosphonates have a slight risk of renal toxicity especially for intravenous (IV) forms that could be reduced by hydration and extended infusion time (4). Both zoledronate and IA have an excellent renal safety profile in osteoporosis treatment with glomerular filtration rate (GFR) $>30 \mathrm{ml} / \mathrm{min}$ (1). Parenteral administration of $\mathrm{IA}$ is recommended in patients with definite contraindication or gastrointestinal diseases $(5,6)$. For the IV injection, the recommended dose of $\mathrm{IA}$ is $3 \mathrm{mg} / 3 \mathrm{dl}$ once every three months. Common possible side effects of IA are stomach pain (such as "gastritis"), indigestion, nausea, having diarrhea or constipation, headache, feeling tired and exhausted, flu-like symptoms including fever, shaking and shivering, feeling of discomfort. Also, some rare side effects such as swelling of the face, lips, tongue, and throat, with difficulty breathing and itching, persistent eye pain and inflammation, new weakness or discomfort or pain, in thighs, hips or groins are defined. But extravasation is the much more rare complication of IA $(5,6)$. The IV IA itself is always an irritant; therefore, the injection should be given 
into the vein, and strict adherence to the IV route of administration is essential. IV catheter application should be performed by a physician or qualified/trained healthcare worker $(5,6)$. Extravasation is the accidental administration of IV infused medications like IA into the extravascular space/tissue around infusion sites, either by leakage (e.g., because of brittle veins in very elderly patients), previous venipuncture (such as from blood drawn for laboratory tests prior to therapy), or direct leakage from mispositioned venous access devices. According to U.S. Food and Drug Administration reports a percentage of IA patients is $0.0900 \%$, where injection site extravasation is a detailed side effect (7). Also, $0.03 \%$ of Zoledronic acid patients reported having extravasation as a side effect $(7,8)$. Extravasation is an infrequent side effect of the I.V. bisphosphonates. Following the guidelines are given below for minimizing the risk of extravasations is vital to prevent this undesired situation.

\section{Guidelines for minimizing the risk of extravasation (3)}

$\square$ Do not site cannula over joint spaces, as this can cause irreparable damage to nerves and tendons should extravasation of vesicant occur

$\square$ Ask patients to report any change in sensation, stinging or burning. Always listen to the patient

\section{$\square$ Never cover cannula site with a bandage}

$\square$ Dilute irritant drugs as much as possible and give at the appropriate rate

Whenever possible, administer vesicant drugs as a bolus

Check for swelling, inflammation, and pain around cannula site during the administration of intravenous drugs

$\square$ Particular vigilance is needed in patients who may not experience the pain of extravasation or are unable to localize the pain - babies, who have diabetes with peripheral neuropathy and patients with decreased level of consciousness

A central line should be used to administer cytotoxic medication.

Yazarlar arasında çıkar çatışması yoktur

The author declares no conflict of interest.

Finansal Destek: yoktur / Funding : none

doi: $* * * * * * * * * * * * * * *$

\section{REFERENCES}

1. Rossini, M., et al., Osteoporosis treatment: why ibandronic acid? Expert Opin Pharmacother, 2013. 14(10): p. 1371-81.

2. Guay, D.R., Ibandronate, an experimental intravenous bisphosphonate for osteoporosis, bone metastases, and hypercalcemia of malignancy. Pharmacotherapy, 2006. 26(5): p. 655-73.

3. Rose, R.F., R \& Crawford-Sykes, Annette \& Venugopal, R \& Wharfe, Gilian \& Arscott, George., Extravasation injuries. The West Indian medical journal, 2008. 57(40): p. 7.

4. Lewiecki, E.M. and P.D. Miller, Renal safety of intravenous bisphosphonates in the treatment of osteoporosis. Expert Opin Drug Saf, 2007. 6(6): p. 663-72.

5. Davis, S., et al., A systematic review and economic evaluation of bisphosphonates for the prevention of fragility fractures. Health Technol Assess, 2016. 20(78): p. 1-406.

6. Veszelyne Kotan, E. and A. Meszaros, [Therapeutic practice of bisphosphonate use and related pharmaceutical issues I]. Acta Pharm Hung, 2016. 86(1): p. 13-22.

7. Study of Possible Correlation Between Injection-SiteExtravasation and Ibandronic Acid. Available from: http://factmed.com/study-ibandronic\%20acid-causing-injectionsite-extravasation.php.

8. Zoledronic acid and Extravasation. Available from: https://www.ehealthme.com/ds/zoledronic-acid/extravasation/

9. Menssen, H.D., et al., Effects of long-term intravenous ibandronate therapy on skeletal-related events, survival, and bone resorption markers in patients with advanced multiple myeloma. J Clin Oncol, 2002. 20(9): p. 2353-9.

10. Diel, I.J., et al., Improved quality of life after long-term treatment with the bisphosphonate ibandronate in patients with metastatic bone disease due to breast cancer. Eur J Cancer, 2004. 40(11): p. 1704-12. 